\title{
Tourism as an exercise in three-dimensional power: Evidence from Ghana
}

\begin{abstract}
This study uses Lukes' (2005) three-dimensional power to explore the ability of traditional chiefs to influence slavery-based heritage tourism decisions. Traditional chiefs of five former slave communities in Ghana were in-depth interviewed about their efforts to harness community development through tourism and perceived influence in tourism decision-making process. Results indicated that despite being guardians of tourism resources, traditional chiefs perceive themselves to be powerless in affecting management decisions because of governmental control of local community institutions. They, however, exert considerable influence on tourism activities by either avoiding engagement or acting as community vanguards to discredit the interests of other stakeholders. Interview data support the theoretical tenets of Lukes' (2005) three-dimensional view of power, and the need to pursue cooperative tourism planning is discussed.
\end{abstract}

Keywords: Traditional chiefs, three-dimensional power, former slave communities, tourism decision-making, cooperative tourism planning, Ghana

\section{Introduction}

The influence of Ghanaian chiefs in slavery-based heritage tourism has lately attracted significant research interest, especially among anthropologists (see, Bruner, 1996; Steegstra, 2012; Silverman, 2015). The main thrust of the argument is that slavery-related sites and slaveryrelated public commemorations are presented as commodified tourism products for international visitors (Bailey, 2005; Greene, 2011; Benson \& McCaskie, 2004; Schramm, 2008b). Similarly, long-held chieftaincy customs have been compromised as foreigners (particularly of African descent) have been installed as development chiefs (nkosuohene in the Akan language) as a means of inducing community development, as well as bolstering the community’s identity and image in the tourism marketplace (Benson, 2003; Bob-Milliar, 2009).

However, much less has been mentioned (or perhaps implicitly assumed) about how the exercise of power by traditional chiefs affects tourism. This point is important to pursue because although the current political dispensation in Ghana removes most of the legal and political 
sovereignty of the chief in council (Quarcoo, 1982), chiefs wield a considerable amount of influence at the community level (Ubink, 2007). Indeed, the socio-political roles played by chiefs in centralized and hierarchical societies during the Transatlantic Slave Trade era weigh heavily as a factor. Bosman (1705:180) reported in the $18^{\text {th }}$ century that "most of the slaves that are offered to us are prisoners-of-war which are sold by the victors as their booty”. This observation is buttressed by historical records that indicate that the bulk of enslaved Africans in the New World were victims of wars and raids instigated by powerful chiefdoms (Der, 1998; Perbi, 2004; Shumway, 2011). Whether contemporary chiefs should acknowledge or be absolved of the complicity of their forebears in slavery remains a matter for disagreement (Gates, 2010; Akurang-Parry, 2010; Keren, 2009).

However, since the abolition of slavery, traditional chiefs in former slave communities have faced a quandary with dire socio-political and economic implications. Those who have acknowledged complicity of their forebears have had to publicly apologize for the past. Still, they find themselves at a loss when repudiating the past, given the prevailing socio-economic conditions in their communities. One background fact to bear in mind is that most residents of former slave communities are unemployed, are unable to access quality health care, clean water, and waste disposal services and have low levels of education (Holden, Sonne \& Novelli, 2011; Ghana Statistical Service, 2014). Under such circumstances, the embrace of tourism as a 'passport' to community development confirms the intuitive understanding that very few options exist (Burns, 1999; Yankholmes, Akyeampong \& Dei, 2009).

The dilemma that the process of atonement presents is further complicated by the United Nations Educational, Scientific, Cultural Organization's (UNESCO) Slave Route Project, which seeks to develop a tourist trade focused on remembrance and the promotion of socio-economic 
development through tourism in former slave communities in Africa, Europe and the Americas/Caribbean (Schramm, 2008b). This goal, although laudable, might not achieve the desired results for many reasons. The primary shortcoming is that the UNESCO Slave Route Project promotes a single global collective memory of slavery. As Ashworth (1997) observed, whenever and wherever ownership of the past is collectivized on a global scale, multiple stakeholders with differing power imbalances and interests attend to it, leading to the reconstruction or transfiguration of that past. In Ghana, gaining recognition as part of the Slave Route Project has become a coveted prize not only for traditional chiefs but also for other stakeholders in former slave communities with intricate connection to slavery. In such a scenario, the different stakeholders are be pitted against each other for control and access to tourist dollars. However, traditional chiefs are at the apex of the community power structure, indicating that they wield considerable influence when decisions about tourism are made at the local level (Wyllie, 1998). Without consideration of the power mechanisms that underlie community tourism, researchers have not only failed to thoroughly investigate the structural characteristics of destination communities which are relevant to their power structures and decision-making process (Blackstock, 2005), but they have also ignored the historical, socioeconomic, political and geographical (or spatial) contexts in which tourism occurs (Beeton, 2006).

The current study investigated the social or psychological mechanisms of power in tourism management decision making and their behavioral outcomes. It argues that traditional chiefs are able to influence slavery-based tourism (either consciously or unconsciously) analogous to Lukes' (2005) three-dimensional power. The goals of this study were to explore the extent to which traditional chiefs attempts to use slavery-based heritage tourism as a 
developmental option and degree of impediments encountered, and their influence in tourism decision-making process. Scholars have long recognized that destination communities are heterogeneous with unequal power relations (Richter, 1999; Ryan, 2002), which may lead to the exclusion of stakeholder groups with opposing views in the decision-making process (Freeman \& Gilbert, 1987; Freeman et al., 2010; Reed, 1997). The ability of chiefs to influence slaverybased heritage tourism has received relatively little research attention (Schramm, 2008a;

Peterson, Gauva \& Rassool, 2015).

\section{Literature review}

\subsection{Lukes' three-dimensional view of power}

This study employs Lukes' (2005) three-dimensional power as the underlying theoretical framework to compare the scope of influence that traditional chiefs of five former slave communities in Ghana have had with tourism. In particular, the aim is to highlight how the historic, socio-economic, political and geographical contexts of former slave communities ascribe an undefined residuum of power to traditional chiefs in tourism decision-making process. Lukes (2005) introduced the third dimension of power to challenge earlier conceptions of power he felt were behaviorally focused. Briefly, the one-dimensional perspective of power is where A (relatively powerful) prevails over B (relatively powerless) in decision-making. Ultimately, “A has power over B to the extent that he can get B to do something that B would not otherwise do" (Dahl, 1957, 202-203). Much of the early community-based tourism planning studies (e.g., Murphy, 1985) reflected insights from the one-dimensional perspective of power by identifying who makes decisions and controls participation in tourism. By the same token, the twodimensional approach to power emphasizes who participates and what is debated in decision- 
making. Pioneered by Bachrach and Baratz (1962: 948), power is exercised when “A devotes his energies to creating or reinforcing social and political values and institutional practices that limit the scope of the political process to public consideration of only those issues which are comparatively innocuous to A. To the extent that A succeeds in doing this, B is prevented, for all practical purposes, from bringing to the fore any issues that might in their resolution be seriously detrimental to A's set of preferences”.

However, Lukes (2005) contended the two previous views particularly the second definition of power is too individualistic. He argued that, rather than simply seeking observable conflicts (overt or covert) from becoming issues in the political arena, we should examine the complex and subtle manners in which the interests of B are very difficult to ascertain with precision, incapable of being expressed or even recognizable at all. To him the most insidious form of power is domination. Lukes (2005:27) goes on to define power as "A may exercise power over B by getting him to do what he does not want to do, but he also exercises power over him by influencing, shaping or determining his very wants”. This conceptualization of power captured its many variants, that is, coercion, influence and authority. He acknowledged that any conceptualization of power in social relationships must imply an answer to the question: 'what counts as a significant manner? ‘what makes A’s affecting B significant?’ (Lukes, 2005:27).

Three related concepts are relevant for empirically identifying the three-dimensional view of power in the absence of actual observable conflicts. The first is the relevant counterfactual and power mechanism. Here, A can affect B, either on his/her own or with other sufficient conditions so that B does what s/he would otherwise not do. However, in a situation in which there is no observable conflict between the two, other conditions must be met regarding the relevant counterfactual. Hence "we need to justify our expectation that B would have thought or acted 
differently; and we also need to specify the means or mechanism by which A has prevented, or else acted (or abstained from acting) in a manner sufficient to prevent B from thinking so" (Lukes, 2005:44). Second, power dwells on the notion of 'real interests' and 'false consciousness'. Lukes observed that, when conflict exists between the preferences of A and B but A's preferences are in B's real interest, two response options present themselves. Lukes' preferred response is that A exercises 'short-term power' over B but ceases when B is able to recognize his/her real interests. He reasoned, however, that A is likely to abuse his/her power and possibly to become tyrannical, but B can avert this situation by being relatively autonomous and operating independently of A's powers. Moreover, B can be misled into believing that sacrificing his/her autonomy is for the best or his/her only viable option. Third and closely related to the previous response to real interests is adaptive preference. Since B's interests are constrained by A, B might adapt to the wants, desires and preferences that conform to the status quo. However, these adaptive preferences might not be what A directly intended. Unlike the first two conditions in which $\mathrm{A}$ is aware of his/her domination, in this case, A does not realize that the power that s/he exercises creates or elicits false consensus from B. What accounts for this crucial difference is that power could be unintentionally wielded, yet B might be quiescent due to misunderstanding of A's domination.

However, the empirical use of Lukesian approach to power is fraught with conceptual and methodological difficulties (Edwards, 2006). Polsby's (1963) question regarding how the researcher knows which non-observable issues to study still persists. Even though Lukes (2005) discussed several empirical studies that found evidence of the relevant counterfactual as satisfactory prove of the operation of his three-dimensional view of power; a comprehensive and convincing answer to Polsby's question was not provided. Haugaard (2010) is more adamant; he 
argues that the third dimension of power does not necessarily lend itself to the exercise notion of power but it rather bifurcates power into either/or decisions. Of greater interest here, is assessing the reliability and validity of the true consciousness of powerholders. Even though, traditional authorities in the current study are very willing to discuss their actual experiences of invisible power to achieve tourism development, they articulate an unchallenged view of their subjective preferences. As such, their frame of reference or plausibility of account is not open to challenge. The three-dimensional power, therefore, needs to consider a multi-evaluative or a two-way confirmatory framework.

Notwithstanding these criticisms, Hall (2003, 2007), drawing on Norkunas (1993), argued that heritage tourism provides a useful setting for elucidating the third dimension of power. However, to the best of the author's knowledge, no studies to date have tested this assumption in non-Western hierarchical destination communities. The current study respond to Hall's (2003, 2007) call to re-engage Lukes' (2005) three-dimensional view of power within heritage tourism, arguing that the power exercised by chiefs in former slave communities has clear resonance with Lukesian approach to power.

\subsection{Implications for the role of traditional authorities in Ghana}

Much has been written about how power is unequally distributed between stakeholders but few have inquired about the quality of power exercised and its outcomes (Mitchell, Angle \& Wood, 1997). This is partly due to the definitional and operational problems of power mentioned above. For the purposes of this study, power is defined as the ability of chiefs to consciously or unconsciously influence tourism decision-making. This definition takes into account the possibility of chiefs doing everything possible to either maintain the status quo or seeking to 
change the community power structure in their favor, or both. The reader should bear in mind that this definition allows for, but does not assume that power in community tourism is exclusively structural. As previously noted, the ability of chiefs in former slave communities to influence tourism is etched into the disreputable trade itself. However, space requirements do not permit an exhaustive review of the literature on the Transatlantic Slave Trade. The reader might wish to consult Lovejoy (2000) and Eltis, Behrendt, Richardson and Klein (1999) for a more comprehensive discussion of the subject.

What conditions, and to what ends can traditional authorities influence tourism? Judging from previous work, several factors that may operate to such effect, including the quality of leadership provided by traditional authorities against the perceived ineptitude of democratically elected officials (Logan, 2008, 2009; Helle-Valle, 2002), the ability of chiefdom administration to complement the modern local government system (Oomen, 2000; Owusu, 1996), state development capability and legitimacy (Englebert, 2000), and the poor government performance or function thereof in the delivery of public services (Bratton, 2010; Ntsebeza, 2004, 2005; Williams, 2010). All of these factors encapsulate the ability of traditional chiefs to influence tourism in former slave communities.

In Ghana, the chieftaincy institution is an indigenous form of government that revolves around the use of a stool or skin as a symbol of office, depending on the geographic area of the country (Quarcoo, 1982). While a chief is nominated, elected and initiated into a stool office in southern Ghana, those in the northern part are initiated into a skin office (for example lion and leopard skins). Traditionally, once the chief is installed; he becomes the judiciary, commanderin-chief, and legislative, executive and administrative head of his people. However, he is only deemed 'primus inter pares' and not a master. He is duty bound by custom to act or to give royal 
assent upon the advice of his 'elders'. If the chief abuses his privileges or ceases to command the respect and trust of the public, he is destooled/deskinned but not vi et armis. He must first be impeached and then proved guilty before being de-stooled or de-skinned (Quarcoo, 1982).

Even though chiefdom administration predates colonial rule in Ghana (1874-1957), successive governments, both colonial and post-colonial, have promulgated a number of constitutional and legislative instruments that removed most of the legal and political sovereignty of the chiefs in council (Ray, 1996). Currently, in addition to undergoing the customary process of nomination, election and assumption of stool/skin office, chiefs must be gazetted by Regional Houses of Chiefs to be able to exercise duties not only sanctioned by custom but also enshrined in the country's constitution. Ghana's Fourth Republican Constitution recognizes and preserves the sanctity of the chieftaincy institution, but it falls short of defining the relationship between the central government and chiefdom administration (Ray, 1996). Given that chiefs are custodians of resources within their jurisdictions, balancing local interests against national priorities in the use and management of shared resources is a major challenge. This challenge is made worse by the constitution, which bars chiefs from engaging in partisan politics. The constitution even goes so far as to require abdication when traditional chiefs engage in partisan politics or seek election to the country's legislative assembly.

Despite this constitutional limitation, traditional chiefs have administrative responsibilities, which come under the supervision of the local government apparatus (Aryee, 1992). Ghana operates according to a decentralized system of governance that vests deliberative, legislative and executive powers in the District Assembly headed by elected or appointed public officers. While the chiefdom administration poses a threat to the authority of district councils, both systems exist side by side, sustaining each other toward a common goal - community 
development. There is now ample empirical evidence that chiefs are important partners in community development (Arhin, 1985; Brempong \& Pavanello, 2006; Hernæs, 2005; Odotei \& Awedoba, 2006). The reality, however, is that the allocation of development projects is highly political, and partisan political goals often underpin how community resources are shared (Fridy, 2007). As a consequence, local-national power imbalances complicate community development. One manner in which chiefs circumvent this complication is by the appointment of development chiefs. According to McCaskie (2002), this designation indicates mobilizing and channeling communal efforts for development. The idea emanated from the Asantehene in 1985 and was later adopted by other paramountcies throughout the country. The appointee could be a local indigene either at home or abroad or a non-Ghanaian expatriate (Kleist, 2011; Mohan, 2008). The latter is mostly preferred because of his/her perceived affluence and expansive network of donors or potential donors.

Of particular importance is bestowing the title of development chief on diaspora Africans, particularly African-Americans in former slave communities. This fact is perhaps the clearest illustration of the chief's quest to atone for the past while, at the same time, 'tapping into their money’ (Bob-Milliar, 2009). For example, the Reverend Dr. Barbara King, founder and leader of the Hillside Chapel and Truth Center of Atlanta, Georgia, donated US\$3,000 to start work on a new agricultural school upon her enstoolment at Nsuta near Assin Manso (Benson, 2003), while Mahar Cooke donated a water storage tank to ease perennial water shortages in Bono Manso (Silverman, 2015). Some have argued against the proliferation of development chiefs because it devalues the sacredness of the chieftaincy institution. Other researchers have claimed that it places communities at risk of American cultural imperialism (McCaskie, 2002). However, Steegstra (2012: 258) argues that the practice does not weaken the authority of the traditional 
chief but instead “... add[s] to the grandeur of his court and offer[s] one of the several modern means for development”.

Several researchers have commented on the community power imbalances and legitimacy issues involved in tourism planning (e.g. Reed, 1997; Tosun, 2000; Timothy, 2002). In these studies, power has been conceptualized as relational, transitive and intransitive (Church \& Coles, 2007). The latter conceptualization of power informs the plethora of tourism research on stakeholder collaboration and participation in both developed destinations and less developed ones, although the former are the overwhelmingly dominant contributors to the literature (Canavan, 2016; Bowen, Zubair \& Altinay, 2016). Particularly, scant attention has been paid in the literature to the power structure and tourism governance in non-Western communities, particularly in sub-Saharan Africa (Mowforth and Munt, 2009; Dieke, 2000; Pearce, Moscardo \& Ross, 1996; Sofield, 2003; Singh, Timothy \& Dowling, 2003). Some work has, however, been undertaken in the context of wildlife conservation and human livelihood in protected areas (Hulme, \& Murphree, 2001; Akama, 1999; Harrison, 1992), as well as heritage tourism (e.g.; Chirikure, Manyanga, Ndoro \& Pwiti; 2010; Ndoro, Mumma \& Abungu, 2008; Schramm, 2008a; Peterson, Gauva \& Rassool, 2015).

However, much of the analysis of the community power structures and the decisionmaking process to be found therein has been done from one perspective with researchers applying network analysis to study power relations between government, local residents, entrepreneurs and special interest groups including non-governmental organizations (Beritelli \& Laesser, 2011, Nunkoo \& Ramikisson, 2012; Scott, Baggio \& Copper 2008). The role of traditional authorities has also been discussed in the literature where it is suggested that chiefs not only use their powers to allot land and other economic resources for tourism development 
(Kimbu \& Ngoasong, 2013) but they are also the ultimate beneficiaries of tourism (Afenyo \& Amuquandoh, 2014). However, no theoretical basis for understanding the role of traditional chiefs exists within the community tourism governance literature and what has been written about traditional authorities has its basis in practice rather than in theory.

\section{Methodology}

\subsection{Study setting}

The data reported here were gathered between January and August 2012 as part of a Ph.D. thesis pertaining to the planning and marketing implications of developing the UNESCO Slave Route Project as tourism product. Five former Transatlantic Slave Trade communities namely Cape Coast, Elmina, Assin Manso, Bono Manso and Salaga were selected for this study (Figure 1).

\section{Insert Figure 1 here}

These five locations differ broadly in history, socio-demographic, economic, political characteristics as well level of tourism development (Table 1). However, they share the same attribute of an emerging or relatively developed slavery heritage sense of place. Cape Coast and Elmina are two of the oldest towns in Ghana, with relatively long histories of tourism. More than three centuries of European settlement in both towns have resulted in a melting pot of cultures African and European. Cape Coast was the headquarters of the British colonial government from 1850 until 1877, when Accra assumed that status. It was the dominant commercial center of the Gold Coast and served as an important port for the export of cocoa. When the port ceased operations in 1963, fishing became the mainstay of the economy (Hinderink \& Sterkenburg, 1975). Elmina (situated $12 \mathrm{~km}$ west of Cape Coast) was the first European settlement on the 
West African coast, with the arrival of the Portuguese in 1471. The Portuguese constructed St. Georges Castle in 1482 and recognized the castle and the native inhabitants around it as citizens of Portugal in 1486 (Bech \& Hyland, 1978). The Dutch seized St. Georges Castle in 1637 and made Elmina the headquarters of the settlements on the Guinea Coast. However, the Dutch abolition of slavery in 1814 changed the economic fortunes of the town, making it dependent more on fishing and salt mining (Feinberg, 1989). Thus, dependence on fishing in both Cape Coast and Elmina prompted the central government to attempt to diversify the local economy. The government undertook major improvement works on the social infrastructure of both towns and then initiated an integrated development plan to deliver much-needed socio-economic improvements for residents. With funding and technical support from the United States Agency for International Development (USAID), the Smithsonian Institute and ICOMOS under a program entitled the Natural Resource Conservation and Historic Preservation Project (NRCPP), the Cape Coast and Elmina castles were rehabilitated as a means of opening the area to tourism. Available quantitative assessments of tourism suggest that residents of both towns feel that they have no say in decisions, which are made solely by the central government (Sirakaya, Teye \& Sonmez, 2002; Teye, Sirakaya \& Sonmez, 2002).

\section{Insert Table 1 here}

Assin Manso and Bono Manso are different in terms of geo-political characteristics and tourism experience (Table 1). Both towns are located on major highways and are considered relatively rural in terms of economic activities and landscape. Assin Manso houses the Slave River (locally called Ndonkonsu), where captives were bathed and sorted out for the coastal forts. The Slave River is the major draw for mostly diaspora African day-trippers, who flock to the town during Emancipation Day and the Pan African Theater Festival (PANAFEST) in August 
and stay away for the rest of the year. The uneven distribution of visitors has resulted in practically no tourism infrastructure except for a visitor reception facility. In contrast, Bono Manso a tenuous connection to slavery. So far, there is little historical evidence regarding its role during the slave era, but a baobab tree has been suggested to be the resting spot for captives trekked from the northern slave market sites such as Salaga. Nevertheless, since 2003, monuments commemorating key black civil rights leaders, such as Dr. Martin Luther King, Marcus Garvey and Malcolm X, have been erected in the town. Oddly, visitors are not visible except for recurrent expatriate diaspora Africans (Silverman, 2015).

Of all of the former communities on Ghana's Slave Routes, Salaga is perhaps the only place that requires no justification for inclusion in any slavery-related study. Salaga's strategic location on several key caravan routes and its role as a terminus for the regional trade in kola nuts caused it to gain popularity as the main artery that supplied captives to the coastal forts (Akurang-Parry, 2001). Its commercial status resulted in a cosmopolitan population that has remained well to date. Tourism first became important to the area when Salaga was included as a major stop on the PANAFEST/Emancipation Day itinerary, given that it was the host of the infamous former slave market, slave baths and slave villages. Although popular among diaspora African 'root seekers', its remoteness from the forts, coupled with limited transportation options, has made it difficult and expensive for holidaymakers. Traditionally, Kpembe (3 km east of Salaga) is the capital of the East Gonja division of the Gonja State, but Salaga is the administrative capital of the East Gonja District Assembly (Okoro, 2008). Though Salaga has a chief; he is appointed by and responsible to the Kpembiwura (paramount chief of Kpembe). 


\subsection{Data gathering and analysis}

The general approach of the fieldwork was inductive, similar to Glaser and Strauss' (1967) ideas about grounded theory. To this end, a mix of data collection methods was employed, including participant observation, in-depth interviews and analysis of official and archival documents. Purposive sampling method was used to select the participants for the study. However, the participants' willingness to communicate their experiences was the main criterion for inclusion. It was assumed that traditional chiefs in the five study areas were the sources of data to increase understanding of the phenomenon under study. Thus, the richness of the text, rather than the sample size, was the more important consideration (McCracken, 1988). Ethical approval was sought and obtained from the Human Subjects Ethics Sub-Committee of the author's institution.

Table 2 provides a brief description of the participants. They were all men in their 60s even though there are some female chiefs in Ghana (Boafo-Arthur, 2003). In consecutive order, the average reign was 25 years, with the chief of Assin Manso being the longest serving paramount ruler.

\section{Insert Table 2 here}

A semi-structured interview schedule was used to guide the discussions. The interviews were 1-2.5 hours long. The participants were asked about: (1) daily life concerns of local residents and their desire for community development; (2) current, past and anticipated experiences of tourism, as well as the nature of community participatory decision-making process; (3) most influential persons or stakeholder groups in community affairs and whether they have any power to influence tourism decision making. To ensure that the participants had the opportunity to discuss experiences consistent with manifestations of the three-dimensional 
view of power, they were prompted about the differences between the chiefdom administration and modern democratic system of governance with regard to participatory decision-making and consensus building processes.

The paramount chiefs of Cape Coast and Assin Manso and the chief of Bono Manso consented to one-on-one interviews, while the remaining interviews were conducted with divisional or sub-chiefs delegated by the traditional councils. The paramount chief of Assin Manso was interviewed at his private residence, while those of Cape Coast and Elmina occurred in the traditional council offices. The chiefs of Bono Manso and Mobuwura (with some subchiefs and elders present) were interviewed in the audience courtyards of their palaces. In the latter case, questions were asked and answered through the royal spokesman, given the long-held custom in many parts of Ghana that precludes direct communication with chiefs in formal settings (Yankah, 1995). The conversations with the paramount chiefs of Cape Coast, Assin Manso and sub-chiefs of the Edina Traditional Council were conducted in English and were later transcribed verbatim while interviews with the chief of Bono Manso and the Mobowuru were conducted in Twi and Gonja respectively. The English version of the schedule was independently translated into these local dialects by bilingual field assistants recruited from each community and trained in ethnographic interviewing procedures. To minimize errors and difficulties due to translation, the interview schedule was pretested on two sub-chiefs in each study area before the final interview schedule was developed to collect the actual data of the study. The conversations were then back-translated into English by a senior translator (an experienced professional translator with the Ghana Institute of Languages responsible for ensuring overall high translations quality in a language pair and who was blind to the original English version) who was a native speaker of the two languages to which the translation was made and checked to 
ensure textual, content and semantic equivalence with the original (Brislin, 1970). Differences with the field assistants were resolved by discussion.

Prior to each interview, the researcher, as part of community entry protocol, presented a bottle of schnapps or kola nut and introductory letters to the traditional authorities seeking their participation in the study (Akyeampong, 1996). After the customary 'greetings', explanations about the study and the signing of consent forms, permission was provided by all of the participants to audio-record the conversations and to report their names and titles with their comments. Therefore, with consent, the participants are identified directly throughout this paper (van der Geest, 2003). Some of the participants objected to anonymization because they felt honored to be selected for the study. Others indicated their frustration with the use of pseudonyms and felt that the current study provided an opportunity for the community to increase its notoriety.

The data were analyzed by adhering to Marshall and Rossman’s (2006) seven steps: organizing, immersion, creating categories and themes, coding, interpreting, searching for alternative interpretation, and writing the report. The researcher reviewed the transcripts repeatedly to achieve immersion and became familiar with the participants' experiences of exercise of invisible power in decision-making. Recurring ideas and words were then identified as salient themes. The themes were then coded using abbreviated keywords, which were later aggregated into categories. The transcripts were reread again to ensure that the final categories captured the interview content. At this stage, the participants' perceptions of Cape Coast and Elmina as prime slavery heritage destinations emerged as an essential category. Thereafter, the participants were grouped by differences in opinions about Cape Coast's and Elmina's successes in tourism, the level of community development and their influence in decision making. By 
systematically contrasting each community's tourism experience and the chief's sense of control in affecting tourism decisions, patterns of participants' exercise of power became clearer. Finally, the findings are reported with direct quotations from the transcripts. To ensure credibility of the data, the researcher explained the questions to the participants and used probing questions whenever possible. An unsuccessful attempt to perform member checking by asking the participants to read their transcripts to ensure accuracy. However, the researcher kept a detailed journal of all of the decisions made, including how many times and under what circumstances the participants were contacted.

Some caveats and limitations to the method must be noted. Three of the five chiefs in the selected study area spoke directly with the researcher, possibly out of intense interest in the study. Therefore, the sample of chiefs selected for this study was not representative of traditional authorities of former slave communities along Ghana's Slave Routes, as the study was not meant to yield valid and generalizable statements about the exercise of power by chiefs. Its prime aim was to gain theoretical insights into power process and mechanisms and the outcomes. Additionally, the unequal power relationship between the researcher and participants was in itself an obstacle. To have direct communicative access to chiefs in formal settings, not to mention asking them questions very directly, is considered a cultural affront. It was also intimidating and awkward to initiate or maintain dialogue with the participants, especially in their royal courtyards. This problem was compounded by the desire of some chiefs to delegate sub-chiefs to speak on their behalf. Although those people selected were knowledgeable about the phenomenon under study, one can only speculate the extent to which their experiences corroborate or conflict with the paramount chief. At times, too they seemed to participate more out of obligation than a genuine interest in the research topic. 


\section{Findings and Discussion}

The following section presents the key findings that emerged from the data used for the present study. First, how the participants described their environments and desire to improve residents living conditions are discussed. Then how the social and structural characteristics of former slave communities underlie the chiefs’ ability to use tourism as a developmental agent and the degree of impediments they experience in the process are described. Finally, the interviewee's attitudes and beliefs about their role in tourism decision-making process and their perceived role of other stakeholders in the management of tourism is discussed.

\subsection{Desire to improve residents’ living conditions}

In order to appreciate the aims of the present work it is necessary to understand the extent to which Chiefs endeavor to improve the living conditions in their areas of jurisdiction. One of the arguments supporting the contemporary socio-political relevance of the chiefs is their ability to articulate the needs and priorities of the community and their ability to mobilize their subjects behind developmental initiatives. In what manner, however, could present-day chiefs be possibly charged with the responsibility of community development when they reside outside the jurisdiction? Recent years have seen chiefs (especially public servants, academics and businesspeople) reside in large cities and towns or abroad and return occasionally to address the most serious local matters. Thus, all of the participants were first asked why they chose to live in the community. The primary unanimous reason that the participants gave was that they were the rightful occupants of the stool/skin. In many respects, the responses were only to be expected given that, at the time of conducting this study, informants from Cape Coast and Elmina were, for instance, contending in civil courts regarding their installation. The interviews showed that 
truth claims were constructed along the general lines of historical knowledge, as the paramount chief of Cape Coast noted.

...I bet many of the people who are fomenting tension regarding chieftaincy in this community don't know the real history and truth - as I do.

Another reason why participants lived in the community all of their lives was because of their psychosocial connections to the history of the areas. In particular, the chiefs of both Assin Manso and Bono Manso were virtually unanimous in ascribing local residents' lifestyles as reflecting the history of the place and the interesting contrast that they present to other communities ("Everyone knows each other"). Both chiefs were convinced that the lack of a basic social infrastructure accounts for their rural character. The context of this imagery was somehow evidenced in Salaga, except that here the past informs a vision of the present, a vision of city life. The Mobuwura noted that the use of the Slave Market site conjures a painful past, but at the same time, it mirrors the hustle and bustle of city life, especially during market days.

Interviewees in Cape Coast and Elmina acknowledged the attraction of the areas' past images as quintessential European towns. For them, such a reputation is attractive to international visitors and should be preserved. However, in the end, their sense of place was influenced by several urban elements, such as availability of modern health facilities, sports and educational facilities, electricity, water sources, public transport and paved streets. For the interviewees, then, the mere presence of these social facilities was a source of social capital.

In all the study areas, the participants desired material wealth and social improvement. Not surprisingly, informants from Assin Manso and Bono Manso tended to want more socioeconomic development. Overall, the participants reported a myriad of socioeconomic problems that emphasized the spatial disparity of development in the country (Songsore, 2003). 
Employment for the youth was by far the single most salient issue for all of the study areas.

Informants bemoaned the high levels of unemployment among the youth, which was reflected in their drift toward the major cities in the country. However, some desired change in living standards were peculiar to a particular locale. For example, the chief of Bono Manso cited safe, clean drinking water as eluding residents for a long time, causing health-related problems. In the case of Assin Manso, the concern regarded inadequate school facilities, while the Mobuwura mentioned inadequate primary health facilities.

Surprisingly, little was said about the role of development chiefs in meeting the dire socio-economic development challenges. A more encompassing thought was that indigenes, both at home and abroad, should actively assist with community development. All of the participants, except for the paramount chief of Cape Coast, had appointed African-American development chiefs, some of whom had initiated and mobilized their own resources to improve standards of living in the study areas. In particular, the chief of Bono Manso spoke about Mahar Cooke as a critical influence on community development.

He bought approximately 46 boxes of books for our library, which is yet to be completed. He has promised to supply more books once the library is completed. ... He also attends our festival every year. At last year's festival, he presented a set of jerseys and footballs to the local team he established and gave toys and clothes to children in the town. He also gives financial handouts to some town folks whenever he visits.

The comment above clearly shows that the community is the major beneficiary of Mahar Cooke's generous handouts. However, it is in this situation that the analysis of Mahar Cooke's ancestry and residential status becomes a non-issue. Though the current study does not report opinions among the beneficiaries regarding Mahar Cook’s generosity, the quote from Nana Menka Ameyaw suggest a classic Lukesian-style case in which absentee development chiefs act 
in the 'real interest' of the community as long as they have made demonstrable and significant contributions toward community development. Besides, by not making Mahar Cook's ancestry and residential status a non-issue, informant from Bono Manso benefits from perceptual bias among the citizenry by claiming credit for ensuring local residents have access to clean drinking water and other development projects.

\subsection{Community development through tourism and feelings of exclusion}

The above scenarios set the context for understanding attempt by chiefs to use tourism to develop their communities and the degree of impediments to this process. From the tone and content of the comments, interest towards developing slavery-based heritage tourism was high among the interviewees. They felt tourism could bring about the desired improvements in living standards particularly for petty traders and peasant farmers. The secretary to the paramount chief of Elmina spoke about the issue directly.

When the tourists come, they patronize local restaurants, and ordinary traders in town reap benefits by selling to the visitors.

In describing how tourism can be applied to community development, informants provided insights into their experience of community-based tourism. The chief of Bono Manso felt that tourism creates public awareness of the importance of education among children, while for an informant in Salaga, it boosts demand for local agricultural products. The paramount chief of Cape Coast recognized that, being the premier tourism destination of choice, Cape Coast carries immense social value even on an international scale.

We get different kinds of people from all over the world through tourism, including the President of United States Barack Obama and several international figures. This has made Cape Coast the envy of Ghanaians. 
Conflicts or negative fallout from tourism seemed to concern informants the least except for the paramount chief of Cape Coast and divisional chiefs of Elmina. In the specific case of Assin Manso, this finding was not surprising given the level of community development and low visibility of visitors. The chief of Bono Manso spoke about employment opportunities when asked about impediments experienced in the process of community development through tourism. In Salaga, there was a sense that the informant was withholding information about impediments experienced in community-based tourism. There was a reason to believe that the informant did not want to discuss such issues because it would suggest weak/poor performance of local government authorities. It was observed that several tourism projects were either uncompleted or abandoned, including a tourist reception facility, due to partisan politics. The traditional authorities resented their neglect and appeared to support an opposition parliamentary candidate who had promised to boost tourism in the run-up to the 2012 presidential and parliamentary elections. Indeed, tourism was a key political issue in the period leading to the elections because tourism is a key developmental issue for all power brokers in the community, including the local government, traditional authorities and aspiring candidates for parliament.

In the light of the discussion given above, it is probably not surprising that some informants felt excluded from the burgeoning demand for tourism. In accordance with the general developmental trend, tourism along the Slave Routes followed a nonlinear trajectory. For Barima Nkyi (paramount chief of Assin Apimanin Traditional Area), the town has become a stopover location rather than an actual destination of choice. The paramount chief described his experience of attempting to attract foreign investors to develop tourism infrastructure in the town:

They usually ask me, "Even if I put a 20-room hotel in Assin Manso, how long do you think I will recoup my capital”? It is only Emancipation Day, which lasts a few hours. 
Who will leave an Accra hotel and stay in Assin Manso? Perhaps some octogenarian who is bidding for his time to see a snake in the wild. Even he wouldn't come because he wants to enjoy himself before he dies. And if he comes for Emancipation Day, he will have his beer and go back because it's a one-day event.

He attributed the inability to promote Assin Manso effectively as a one-stop destination for diaspora African root seekers to several reasons. One was the lack of complementarity of sites on the Slave Routes. He was certain of increased visitation if Assin Manso were part of the bundle of sites offered to visitors to the Cape Coast and Elmina castles (Yankholmes \& McKercher, 2015). The second and perhaps most important reason was government inclusion of Assin Praso as a commemorative site for PANAFEST/Emancipation Day events. On this point, he berated the government for aiding and abetting the erasure and rewriting of history, making the case forcibly that Assin Praso played no significant role during the slaving era. This position supported Benson and McCaskie’s (2004) claim that there is commercial exploitation of slave memory in Ghana. It is, however, important to bear in mind that visitation to Assin Manso was markedly seasonal even before the inclusion of Assin Praso as a site of commemoration.

Somewhat paradoxically, the chief of Bono Manso voiced similar misgivings about the town's non-participation in the Slave Route Project. The dominant pattern in the conversation was that, despite efforts exerted by the traditional council and a community-based organization (the now defunct Centre for African Arts and Civilization) to create appealing primary attractions to transform the area's image, as well as instituting commemorative events to link these attractions, there has been hardly any effect on tourist demand. In particular, Nana Menka Ameyaw felt that efforts at having diaspora Africans visit, stay and spend money have come to naught. Here again, he credited Mahar Cooke and the defunct community based organization with helping to attracting African-Americans: 
She [the mother of Mahar Cooke] impressed upon the Ministry of Tourism to include Bono Manso in this year's PANAFEST/Emancipation festivities, so if everything goes as planned, we will have a grand durbar on July 26 ... She has also promised to come along with more than 300 diaspora Africans.

However, this observation must be considered with circumspection. Although reliable statistics are not available, there are reasons to believe diaspora African root-seekers are less familiar with Bono Manso, less willing to spend time visiting its slave site and less willing to invest substantial emotional resources to engage the place. Silverman (2015) made similar observations about the community’s misjudgment of tourist demand, especially from the diaspora African market.

Similarly, informants from Salaga also expressed a feeling of exclusion from official tourism development and promotion. The Mobowura Asumani Abubakar (chief of the autochthonous people of Kpembi) felt that local government had not succeeded in creating a high-quality tourism product, compared to Cape Coast and Elmina. It was not a comforting thought for him that the iconic Slave Market and associated Slave Wells have not drawn many visitors to the area. Mobowura Asumani Abubakar attributed unsuccessful attempts at stimulating consumption of the area to, as Der (1998) suggested, political hegemony and appropriation of the Slave Trade with its attendant tourism benefits by the coastal fort communities.

.... We've got the Slave Market as evidence of slavery, so why would anybody go to Cape Coast.

A royal councilor at the Mobowura's palace continued:

... we think the Slave Market site heavily contrasts the Cape Coast castle and Elmina castle because they do not engender 'real' and 'nostalgic' feelings about the past [to which the Mobowura added a clarification: the heritage experiences here are more authentic]. 
These comments illustrate how latent conflicts of the past become overt in terms of the site that has symbolic potency in reconnecting diaspora Africans to the traumatic experiences of their progenitors. In making this connection, the informants in Salaga were also expressing another important theme - the widespread complaint of bias of UNESCO in its designation of the coastal forts as World Heritage Sites and the innate sense of disinheritance among communities whose slave-related sites have not earned such accolade. Judging from the comments, there appears to be a misplaced belief that this designation does not only preserve such places but leads to automatic tourism, which would bring the much-needed economic benefits such as jobs and income. Thus, by bringing out into the open the issue of 'whose heritage' and by questioning the fairness of the designation of slave sites as World Heritage, informants in Salaga underscored Hall's (2007) suggestion that international and supranational organizations, in a Lukesian sense, ideologically structure the 'rules of the game' in tourism. Here it has been shown how UNESCO's implicit assumption that the Slave Routes can be presented as a tourist product without discussion of the different articulation of collective slave memories between and among different communities suppresses some communities' sense of place, while placing others in a preferential position in tourism.

\subsection{Influence in tourism decision-making process}

Except for Osabarima Kwesi Atta II (paramount chief of Cape Coast), who chairs many local tourism management committees and boards, the participants felt as sense of powerlessness in effecting tourism decisions. Although local government officials consult chiefs and seek their support on tourism-related projects, the participants told about being ignored or inadequately consulted most of the time. Their comments included frequent expressions of such phrases as 
"the government has the power”, "I don’t feel there is much I can do to affect decisions made the government", "if the government want things done this way, who am I to say no" and "not able have any control". However, as they have become eminently aware that they are the ultimate custodians of tourism resources, they felt that they had legitimate interest in the decision-making process. References were made to several projects that failed because local government officials dominated the decision making and discounted the chief's role in the management of tourism. This finding is in accord with the research findings of Tosun (2006) who attributed the laissezfaire attitude of local government agencies to collaborative decision making to power play.

Implicit in many of the comments and observations was a lack of coordination (let alone cooperation) between the participants and local governing authorities and public bodies. This finding is important for the collaborative and cooperative tourism planning literature. AduAmpong (2014) claimed that formal coordination between public and private sector stakeholders does not exist in Ghana's Central Region (considered to be the hub of the country's tourism industry) because of centralized tourism planning and inadequate capacity of public and private institutions. Certainly, no evidence for this conclusion exists in the current study. An alternative explanation, consistent with the data, is that of distrust of successive ruling governments about the political neutrality of traditional chiefs. Several examples were quoted in the interviews that seemed to suggest that some participants were allied with either the governing party or with opposition political parties. Those who benefited from government support were well placed politically to promote their communities' interests and to extend their influence over the local government administration. Granovetter (2005) noted that social structure affects economic outcomes in three possible ways of which the confidence that other stakeholders will do the "right" thing despite a clear balance of incentives to the contrary was by far the most important. 
Echoing the same spirit, the participants explained that the antidotes to the lack of coordination, was to give the chiefs a leading role in the early stages of the decision-making process and to create a framework governing the management of tourism that involves chiefs. Yet they also reckoned establishing a clear communication path with local or central government officials was the significant hurdle to overcome given the extent to which partisan politics influence decision making about community development.

However, it appeared that the participants' sense of powerlessness in affecting tourism decisions were broken in some circumstances. Public commemorations, such as PANAFEST/Emancipation Day celebrations, allowed them to wield a dominant influence and increase their political power, especially when it involved performing spiritual rituals or appearing at the occasion to give it the importance it deserves. In these situations, they were courted not only by the Ministry of Tourism and local government officials to lend their voices on behalf of the community but also by the expatriate diaspora African community, which uses such occasions to forge a sense of collective identity with community members. They reported feeling significantly in control because other stakeholders depended on their patronage.

But in practice chiefly absolutism and influence in commemorative practices, meant that they inscribed their version of history on the community's collective slave memory. The data show that slave memories articulated by some stakeholders are discredited or suppressed because they do not fit into the official discourse of the past, or they are omitted because they threaten community identity. The latter case was particularly evident in Salaga, where the data shows there was no overt conflict over heritage representation, although anecdotal evidence confirms a groundswell of conflicting narratives exist based on who is invoking the past. Apparently, the 
traditional council avoids alternative narratives of slavery because it ensures a bounded sense of place (Der, 1998; Perbi, 2004).

A more visible outcome of participants' exercise of power was pushing the zero-sum contestations of ownership of tourist attractions in their respective communities as earlier reported by Bruner (1996). Typical scenarios were reported in Elmina and Assin Manso. The Elmina Traditional Council was withholding support for tourism because of the failure of the government to agree to a fair and transparent framework for tourism revenue sharing. Apparently, the government in power at the time of the study did not recognize the arrangement made by the previous government, whereby the traditional council received a portion of the revenue accrued from visitations to the Elmina Castle. Thus, the traditional council has been reluctant to restrain boat builders who have encroached the buffer zone around the castle (Figure 2). The Museum and Monument Board, which holds legal custody of the castle, was unable to evict the encroachers because of claims that the parcel of land is a communal property. Thus, the Elmina Traditional Council's abstinence in tourism was to discredit the legitimacy of the Museums and Monument Board, while entrenching the traditional councils' resource power.

\section{Insert Figure 2 about here}

Similarly, there was a simmering legitimacy contest between the paramount chief of the Assin Apimanin Traditional Area and the local district council regarding proceeds from tours to the Slave River. Much to the chagrin of the local authorities, the paramount chief had occasionally taken over the management of the tourist reception facility. When asked about this issue, Barima Nkyi justified his actions. He recounted several foreign trips he had undertaken to bring investment to the community without assistance from the local authorities. He said that 
tourism-generated proceeds might be better allocated to improve the social and economic wellbeing of the residents, rather than their being siphoned off by corrupt politicians.

Right now, whatever I get by way of royalties is very minuscule. I get only $24 \%$, and $55 \%$ is pumped into the local council. What do I get? Nothing ... For the past eight years that we jumped into this new era of governance, nothing, not even a public toilet, has been provided for this community ... And you hear what is going on? If it is true ...

There were other instances that the effectiveness of participants to exert influence on the outcome of tourism were manifestation of the wider social norms and power structures. This was evidence when asked to name persons or groups who are influential in community affairs and what role if any, such influencers should play in tourism. All respondents mentioned the district assembly. This seems an intuitively obvious finding considering the fact that the district councils control the public purse and therefore hold the key to inducing community development. Other persons or groups mentioned as community influencers include local residents, expatriate diasporan Africans, tourism entrepreneurs and descendants of slaveholders in that order. Descendants of 'slaves' received no mentions as most influential in all the study areas except Salaga. It thus became evident that social status was the criterion of inclusion of people or stakeholders the informants perceived to be most influential or capable of influencing tourism decisions.

But when asked whether descendants of 'slaves' have ability to affect tourism decisions, all of the interviewees reminded the researcher about the social taboo that proscribes public disclosure of people’s ancestry (“How are you going to find them?” the chief of Assin Manso asked). Not only did participants explain why issues relating to slave ancestry were seldom discussed openly, but they also pointed out why there is an age-old taboo with harsh punishments on tracing someone’s ancestry ("You don't have to know", insisted the secretary to the 
paramount chief of Elmina). In all of the study areas except for Salaga, there was talk about descendants of 'slaves' having being assimilated into society ("We have an Akan proverb that says: if a white cockerel stays too long in the house, its color changes”). However, it was observed that, while it is not socially acceptable to talk about people's ancestry, differentiating between commoners and descendants of 'slaves' tends to be less of an open secret. Inadequate listing of local residents means that people of slave lineage are known and identified by their names and facial marks, by inscriptions on buildings and by descendants of slaveholders' accounts and inventory. These methods have currently become contentious because of numerous and acrimonious family inheritance and chieftaincy succession feuds, especially in Cape Coast and Elmina (Bailey, 2005; Greene, 2011; Schramm, 2008b).

The data suggest that two reasons account for why the taboo associated with people's ancestry is still in place and adhered to: first, there was no real danger of local residents questioning the chief or casting doubt on the sanctioning process; and second, compliance preserves the status quo in the existing balance of power. The latter is possible because residents prefer the chiefs' 'courts' to adjudicate cases involving violations of the taboo, despite their judiciary powers having been rigidly curtailed. Recall Lukes (2005) acknowledging that powerholders attribute 'real interest' and 'false consciousness' to others to deny them alternatives to the status quo. In this case, the taboo on slave ancestry is only as strong as preventing the open identification of descendants of 'slaves', but its compliance is best for the general welfare of society or is their only option. Similar examples of compliance with social norms based on power and trust was reported by Lyon (2005) in his study of informal cooperative associations in Ghana. 
When probed further about descendant of 'slaves' role in decision making, there were uncanny repetitions of which person or stakeholders were active participants in tourism or capable of influencing management decisions. The data demonstrated that the chiefs in the present study occupied that space because of their perceived constraints of interest on the part of the lower class and status groups, particularly descendants of 'slaves'. Acting in the perceived interest of the lower echelons within the power structure of the community invariably entrenches the unbalanced power relations. The paramount chief of Assin Manso summed up many of the expressions well:

We know them, but one funny thing is that this is the third or fourth generation. So, what do you think you can get from the third generation?

As is plain from the above quote, Barima Nkyi felt that descendants of 'slaves' have little or no interest to participate in tourism decision-making. Again, except in Salaga, social roles reflected the prevailing social hierarchy. Interviewees in Cape Coast, Elmina, Bono Manso and Assin Manso spoke about defined social roles, even within the royal households ("He is heir apparent but cannot ascend to the status of chief”). The current study found evidence supporting Shumway's (2011) claim that descendants of slaveholders held sway over descendants of 'slaves' in Cape Coast and Elmina, based on the latter's economic status and closeness to wellheeled political elites. It might be interesting to empirically explore the degree of power that descendants of 'slaves' perceive themselves to have and how their stigmatized representation would affect their influence in tourism decision-making. However, these issues are beyond the scope of the current study. 


\section{Conclusions}

This study has discussed the conditions under which chiefs with varied power structures influence tourism decision- making process. The issues identified as relevant to chiefs’ power capabilities were dependent on the power structure of the local communities as well as the wider social, economic and political forces and level of tourism development. The study suggests that while places such as Cape Coast and Elmina have relatively developed infrastructure projects and receives tourism all year, the remainder receives only a handful of day-trippers, mostly during public commemorations. To this end, participants in Cape Coast and Elmina have some ability to influence tourism decision-making. At the same time, because tourism has not yet seriously altered livelihoods in Bono Manso, Assin Manso and Salaga, the informants there found the impacts of tourism on Cape Coast and Elmina desirable and worthy of emulation. Given the prevailing severe living conditions, there is a natural desire to develop these communities through slavery-based heritage tourism. However, chiefs in these places have a relatively small degree of influence to generate tourism capable of advancing community development.

The findings confirmed the soundness of Lukes’ (2005) framework for analyzing power exercised by chief and their outcomes. The previous studies on slavery-based heritage tourism did not evaluate empirically the quality of power wielded by traditional chiefs and their outcomes. The current study returned evidence that chiefs exercise their functions to influence tourism-related projects. The outcomes of the chiefs' influence include the possession of resource power, withholding participation in slavery-based heritage tourism activities, ensuring compliance to social taboos about slave descent, and constraining the 'real interest' of stakeholders they perceive as having less authority and voice in tourism decision-making. 
However, the deployment of power capabilities by chiefs is significantly constrained. Tourism is centralized within the local government administration and other public bodies: chiefs are consulted when they deem it necessary. Therefore, in essence, how the community as a whole is developed or its image promoted for tourism is placed in the hands of the local government and statutory bodies, with or without a presence in the community. The process of community-led tourism management appeared to be absent, with its attendant lack of coordination among chiefs, local administrators and relevant public bodies (Reid, Mair \& George, 2004; Tosun, 2000). The findings suggested that chiefs have no locus of control in decision-making. They usually influence tourism decisions by way of recommendations, which the local councils may either act on or ignore. Consequently, the ownership and management of tourist attractions emerged ass thorny issues in Elmina and Assin Manso because the social structure of these communities affects important tourism outcomes.

Because the integration of theory and empirical evidence offered here confirms Burns (1990) and Dieke’s (2000) dictum that many African countries use tourism as a development tool with little or no influence in the decision-making process, it might be interesting to speculate briefly about the practical and theoretical implications that could be drawn from this study. From the practical perspective, tourism planners/developers must take seriously the importance of traditional chiefs in the power structure of local communities and decision-making process. The results demonstrate how the lines of power in former slave communities tend to have their ultimate source in the stool/skin. Collectively, these results provide some support for the cooperative tourism planning approach advocated by Timothy (1998). In this stance, involving traditional chiefs in local tourism management might be uniquely useful for two reasons. First, given the many social and economic problems bedeviling former slave communities, chiefs there 
are better placed to educate local residents about the demands and expectations of tourism. The second advantage of involving chiefs in local management decision derives the degree of influence they exert on other stakeholders. Even though the informants in the present study may have perceived themselves to be powerless in some instances, they still in practice exercise power traditionally inherent in the stool or skin. This makes it easy for cooperative tourism planning and management interventions because community stakeholder groups can be mobilized and organized to obtain a consensus that will be supported. Obviously, these reasons should be addressed by future research examining how the different community stakeholder groups view the participatory decision-making process and the how traditional chiefs' exercise of power impacts this process.

Theoretically, the current study contributes to the increasing body of literature calling for a redefinition of three-dimensional power from political acquiescence (Gaventa, 2006). The results support the view that the mere acknowledgment of powerless people of powerholders as well as presence of powerholders who do not exercise power or powerholders primed to feel powerless is a sufficient condition to constrain decision-making. The data indicate (other things being equal) even though traditional chiefs do not exercise effective political power, the pursuit of socio-economic development through tourism elicit a certain way of thinking and acting among community members and other stakeholders with vested interest that empower traditional chiefs. It is recommended that future empirical studies on Lukes' (2005) three-dimensional view of power consider the social and psychological situations operating at every stage of the research process to ensure that mentalities and machinations of three-dimensional power emerge from the data alone. 


\section{References}

Adu-Ampong, E. (2014). Divided we stand: Institutional collaboration in tourism planning and development in the Central Region of Ghana. Current Issues in Tourism, 20(3), 295-314.

Afenyo, E.A. \& Amuquandoh, E.F. (2014). Who benefits from community-based ecotourism development? Insights from Tafi Atome, Ghana. Tourism Planning \& Development, 11(2), 179-190.

Akama, J.S. (1999). Marginalisation of the Maasai in Kenya. Annals of Tourism Research, 26(3), 716- 718.

Akurang-Parry, K. (2001). Rethinking the "Slaves of Salaga: Post-proclamation slavery in the Gold Coast (Colonial Southern Ghana), 1874-1899. Left History, 8(1), 33-60.

Akurang-Parry, K. (2010). Ending the slavery blame-game by Henry L. Gates Jr.: Some perspectives. Retrieved on 30/3/2011 from http://www.ghanaweb.com/GhanaHomePage/features/artikel.php?ID=180999http://www. ghanaweb.com/GhanaHomePage/features/artikel.php?ID=180999.

Akyeampong, E. (1996). Drink, power, and cultural change: A social history of alcohol in Ghana. Portsmouth: Heinemann

Arhin, K. (1985). Traditional rule in Ghana: Past and present. Accra, Sedco Publishing. Aryee, J.R.A. (1992). Decentralization under Ghana’s Fourth Republican Constitution. Verfassung und Recht in Übersee/Law and Politics in Africa, Asia and Latin America, 25(4), 394-406

Ashworth, G.J. (1997). Is there a world heritage? The Urban Age, 4, 12.

Bachrach, P., \& Baratz., M.S. (1962). Two faces of power. The American Political Science Review, 56(4), 947-952. 
Bailey, A.C. (2005). African voices of the Atlantic Slave Trade: Beyond the silence and shame. Boston: Beacon Press.

Bech, N., \& Hyland, A.D.C. (1978). Elmina: A conservation study. Occasional Report No. 17. Kumasi, Ghana: Faculty of Architecture, University of Science and Technology.

Beeton, S. (2006). Community development through tourism. Collingwood, Australia: Land Links.

Benson, S. (2003). Connecting with the past building the future: African Americans and chieftaincy in southern Ghana. Ghana Studies, 6, 109-133.

Benson, S., \& McCaskie, T.C. (2004). Asen Praso in history and memory. Ghana Studies, 7, 93113.

Beritelli, P., \& Laesser, C. (2011). Power dimensions and influence reputation in tourist destinations: Empirical evidence from a network of actors and stakeholders. Tourism Management, 32(6), 1299-1309.

Blackstock, K. (2005). A critical look at community based tourism. Community Development Journal, 40(1), 39-49

Boafo-Arthur, K. (2003). Chieftaincy in Ghana: Challenges and prospects in the $21^{\text {st }}$ century. African and Asian Studies, 2(2), 125-153.

Bob-Milliar, G.M. (2009). Chieftaincy, diaspora, and development: The institution of nksuohene in Ghana. African Affairs, 108/433, 541-558.

Bosman, W. (1705). A new and accurate description of the Coast of Guinea, divided into the Gold, the Slave and the Ivory Coast. London: J. Knapton \& D. Midwinter.

Bowen, D, Zubair, S., \& Altinay, L. (2016). Politics and tourism destination development: The evolution of power. Journal of Travel Research, 56(6), 725-743. 
Bratton, M. (2010). Citizen perceptions of local government responsiveness in Sub-Saharan Africa. Michigan State University: Afrobarometer Working Paper No. 119.

Brempong, A., \& Pavanello, M. (2006) Chiefs in development in Ghana: Interviews with four paramount chiefs in Ghana. Accra: Institute of African Studies/University of Ghana, Legon.

Brislin, R. (1970). Back-translation for cross-cultural research. Journal of Cross-Cultural Psychology, 1(3), 186-216.

Bruner, E.M. (1996). Tourism in Ghana: The representation of slavery and the return of the Black Diaspora. American Anthropologist, 98(2), 290-304.

Burns, P. (1990). Paradoxes in planning tourism: Elitism or Brutalism? Annals of Tourism Research, 26(2), 329-348.

Canavan, B. (2016). Tourism stakeholder exclusion and conflict in a small island. Leisure Studies, 36(3), 409-422.

Chirikure, S, Manyanga, M, Ndoro, W., \& Pwiti, G. (2010). Unfulfilled promises? Heritage management and community participation at some of Africa's cultural heritage sites. International Journal of Heritage Studies, 16(1-2), 30-44.

Church, A., \& Coles, T. (eds.) (2007). Tourism, power and space. London. Routledge.

Dahl, R.A. (1957). The concept of power. Behavioral Science, 2(3), 201-215.

Der, B.G. (1998). The Slave Trade in Northern Ghana. Accra: Woeli Publishing Services.

Dieke, P.U.C. (ed.) (2000). The political economy of tourism development in Africa. New York: Cognizant Communication

Edwards, P. (2006). Power and ideology in the workplace going beyond even the second version of the three- dimensional view. Work, Employment and Society, 20(3), 571-581. 
Eltis, D, Behrendt, S.D., Richardson, D., \& Klein, H.S. (eds.) (1999). The Trans-Atlantic Slave Trade: A database on CD-ROM. Cambridge: Cambridge University Press.

Englebert, P. (2000). State legitimacy and development in Africa. Boulder, CO: Lynne Rienner Publishers.

Feinberg, H.M. (1989). Africans and Europeans in West Africa Elminans and Dutchmen on the Gold Coast during the Eighteenth Century. Transactions of the American Philosophical Society, 79(7). i-xvi+1-186

Freeman, R. E., \& Gilbert, D. R. (1987). Managing stakeholder relationships. In S.P. Sethi \& G.M. Falbe (Eds.), Business and society: Dimensions of conflict and cooperation (pp. 397-423). Lexington, MA: Lexington Books.

Freeman, R. E., Harrison, J. S., Wicks, A. C., Parmar, B. L., \& Colle, S. D. (2010). Stakeholder theory: State of the art. Cambridge: Cambridge University Press.

Fridy, K.S. (2007). The elephant, umbrella, and quarrelling cocks: Disaggregating partisanship in Ghana’s Fourth Republic. African Affairs, 106(423), 281-305

Gates, H.L. (2010, April 22). Ending the slavery blame-game. New York Times, p. A27.

Gaventa, J. (2006). Finding the spaces for change: A power analysis. IDS Bulletin, 37(6), 6-23.

Ghana Statistical Service (2014). Ghana living standards survey Round 6: Main report. Ghana Statistical Service: Accra.

Glaser, B.G., \& Strauss, A.L. (1967). The discovery of grounded theory. Chicago: Aldine Granovetter, M. (2005). The impact of social structure on economic outcomes. Journal of Economic Perspectives, 19(1), 33-50.

Greene, S.E. (2011). West African narratives of slavery: Texts from late nineteenth-and early twentieth-century Ghana. Bloomington: Indiana University Press 
Hall, C.M. (2003). Politics and place: An analysis of power in tourism communities. In: Singh S, (eds.) Tourism in destination communities (pp.99-113). Cambridge, MA: CABI Publishing.

Hall, C.M. (2007) Tourism, governance and the (Mis-)location of power. In: Church, A. and Coles, T. (eds.) Tourism, power and space (pp. 247-269). London: Routledge.

Harrison, D. (1992). Tourism and the less developed countries. Chichester: Belhaven Press. Haugaard, M. (2010). Power: A ‘family resemblance’ concept. European Journal of Cultural Studies, 13(4), 419-438.

Helle-Valle, J. (2002). Seen from below: Conceptions of politics and the state in a Botswana village. Africa, 72(2), 179-202.

Hernæs, P. (ed.) (2005) The 'traditional' and the 'modern’ West African' (Ghanaian) history; Case studies on co-existence and interaction. African Series No. 7. Trondheim: Norwegian University of Science and Technology.

Hinderink, J., \& Sterkenburg, J. (1975). Anatomy of an African town: A socio-economic study of Cape Coast, Ghana. Utrecht: State University of Utrecht,

Holden, A, Sonne, J., \& Novelli, M. (2011) The poor's interpretations of the role of tourism in poverty reduction in Elmina, Ghana. Journal of Tourism Planning and Development, 8(3), 317-334.

Hulme, D., \& Murphree, M. (2001). Community conservation as policy: Promise and performance, In Hulme, D., \& Murphree, M. (eds.), African wildlife and livelihoods: The promise and performance of community conservation (pp. 280-297). Cape Town: David Phillips 
Keren, E. (2009). The Transatlantic Slave Trade in Ghanaian academic historiography: History, memory, and power. William and Mary Quarterly, Third Series, 66(4), 975-1000.

Kimbu, N.A., \& Ngoasong, M.Z. (2013). Centralized decentralization of tourism development: A network perspective. Annals of Tourism Research, 40, 235-259.

Kleist, N. (2011). Modern chiefs: Tradition, development, and return among traditional authorities in Ghana. African Affairs, 110/441, 629-647.

Logan, C. (2008). Traditional chiefs in modern Africa: Can democracy and the chief coexist. Michigan State University, Afrobarometer Working Paper No. 93.

Logan, C. (2009). Selected chiefs, elected councilors, and hybrid democrats: Popular perspectives on the co-existence of democracy and traditional authority. Journal of Modern African Studies, 47(1), 1-29.

Lovejoy, P.E. (2000). Transformations in slavery. Cambridge: University Press.

Lukes, S. (2005). Power: A radical view (2 ${ }^{\text {nd }}$ ed.). London: Macmillan.

Lyon, F. (2005). Managing co-operation: Trust and power in Ghanaian associations. Organization Studies, 27(1), 31-52.

Mamdani, M. (1996). Citizens and subjects: Contemporary Africa and the legacy of late colonialism. Princeton: Princeton University Press.

Marshall, C., \& Rossman, G.B. (2006). Designing qualitative research. Thousand Oaks, CA: Sage.

McCracken, G. (1988). The long interview. Newbury Park, CA: Sage.

Mitchell, R., Agle, B., \& Wood, D. (1997). Towards a theory of stakeholder identification and salience: Defining the principle of who and what really counts. Academy of Management Review, 22(4), 853-886. 
Mohan, G. (2008). Making neoliberal states of development- the Ghanaian diaspora and the politics of homelands. Environment and Planning D: Society and Space, 26, 464-479

Mowforth, M., \& Munt, I. (2009). Tourism and sustainability: Development, globalisation and new tourism in the Third World ( $3^{\text {rd }}$ ed.). New York: Routledge.

Murphy, P.E. (1985). Tourism: A community approach. New York: Methuen.

Ndoro, W, Mumma, A., \& Abungu, G. (eds.) (2008). Heritage and the law: Protecting immovable heritage in sub-Saharan Africa. Rome: ICCROM Conservation Studies 8.

Norkunas, M.K. (1993). The politics of memory: Tourism, history, and ethnicity in Monterey, California. Albany, NY: State University of New York Press.

Ntsebeza, L. (2004). Democratic decentralisation and traditional authority: Dilemmas of land administration in rural south Africa. European Journal of Development Research, 16(1), 71-89.

Ntsebeza, L. (2005). Democracy compromised: Chiefs and the politics of the land in South Africa. Leiden and Boston: Brill Academic Publishers.

Nunkoo, R., \& Ramkissoon, H. (2012). Power, trust, social exchange and community support. Annals of Tourism Research, 39(2), 997-1023.

Odotei, I.K., \& Awedoba, A.K. (eds.) (2006). Chieftaincy in Ghana: Culture, governance and development. Accra: Sub-Saharan Publishers.

Okoro, A.O. (2008). Reflections on the oral traditions of the Nterapo of the Salaga area. History in Africa, 35, 375-400

Oomen, B. (2000). Tradition on the move: Chiefs, democracy and change in rural South Africa. Amsterdam: Netherlands Institute for Southern Africa. 
Owusu, M. (1996) Tradition and transformation: Democracy and the politics of popular power in Ghana. Journal of Modern African Studies, 34(2), 307-343.

Pearce, P., Moscardo, G., \& Ross, G. (1996). Tourism community relationships. London: Pergamon Press

Perbi, A.A. (2004.) A history of indigenous slavery in Ghana from the 15th to the 19th century. Accra: Sub-Saharan Publications.

Peterson, D.R, Gavua, K., \& Rassool, C. (eds.) (2015). The politics of heritage in Africa. New York: Cambridge University Press.

Polsby, N. (1963). Community power and political theory. New Haven: Yale University Press. Quarcoo, A.K. (1982). Socio-political relevance of chiefship in contemporary Ghana. Research Review, 10(1), 21-37.

Ray, D.I. (1996). Divided sovereignty- Traditional authority and the State in Ghana. The Journal of Legal Pluralism and Unofficial Law, 28(37-38), 181-202.

Reed, M. (1997). Power relations and community based-tourism planning. Annals of Tourism Research, 24(3), 566-591.

Reid, D.G, Mair, H., \& George, W. (2004). Community tourism planning: A self-assessment instrument. Annals of Tourism Research, 31(3), 623-639.

Richter, L.K. (1999). The politics of heritage tourism development: Emerging issues for the new millennium. In Pearce, D.G., \& Butler, R.W. (eds.). Contemporary issues in tourism development (pp. 108-126). London: Routledge.

Ryan, C. (2002). Equity, management, power sharing and sustainability-issues of the "new tourism”. Tourism Management, 23(1), 17-26. 
Sautter, E.T., \& Leisen, B. (1999). Managing stakeholders: A tourism planning model. Annals of Tourism Research, 26(2), 312-328.

Schramm, K. (2008a). Struggling over the past: The politics of heritage and homecoming in Ghana. Berlin: Free University

Schramm, K. (2008b). Slave Route Projects: tracing the heritage of slavery in Ghana. In: de Jong F and Rowlands M (eds.) Reclaiming heritage: Alternative imaginations in West Africa (pp. 71-98). Walnut Creek: Left Coast Press,

Scott, N, Baggio R., \& Cooper, C. (2008) Network analysis and tourism: From theory to practice. Clevedon, UK: Channel View.

Shumway, R. (2011). The Fante and Transatlantic Slave Trade. Rochester, NY: University of Rochester Press.

Silverman, R. (2015). Of chiefs, tourism and culture: Heritage production in Contemporary Ghana. In Peterson, D.R., Gavua, K., \& Rassool, C. (eds.) The politics of heritage in Africa (pp.113-132). New York: Cambridge University Press

Singh, S, Timothy, D.J., \& Dowling, R.K.(eds.) (2003). Tourism in destination communities. Cambridge, MA: CABI Publishing.

Sirakaya, E, Teye, V., \& Sönmez, S. (2002). Understanding residents' support for tourism development in the Central Region of Ghana. Journal of Travel Research, 41(1), 41-57

Sofield, T.H.B. (2003). Empowerment for sustainable tourism development. Amsterdam: Pergamon.

Songsore, J. (2003). Towards a better understanding of urban change: Urbanization, national development and inequality in Ghana. Accra: Ghana Universities Press 
Steegstra, M. (2012). Becoming 'real African king and queens: Chieftaincy, culture and tourism in Ghana. In van Beek W., \& Schmidt, A. (eds.). African hosts and their guests: Cultural dynamics of tourism (pp. 256-272). New York: Boydell and Brewer Ltd, pp.

Teye, V, Sirakaya, E., \& Sonmez, S. (2002) Residents’ attitudes toward tourism development. Annals of Tourism Research, 29(3), 668-688.

Timothy, D.J. (1998). Cooperative tourism planning in a developing destination. Journal of Sustainable Tourism, 6(1), 52-68

Timothy, D.J. (2002). Tourism and community development issues. In Sharpley, R., \& Telfer, D.J. (eds.) Tourism and development: Concepts and Issues (pp. 149-164). Cleevdon: Channel View Publications.

Tosun, C. (2000). Limits to community participation in the tourism development process in developing countries. Tourism Management, 21(6), 613-633.

Tosun, C. (2006). Expected nature of community participation in tourism development. Tourism Management, 27(3), 493-504.

Ubink, J. (2007). Traditional authority revisited: popular perceptions of chiefs and chieftaincy in peri-urban Kumasi, Ghana. Journal of Legal Pluralism, 39(55), 123-161.

van der Geest, S. (2003). Confidentiality and pseudonyms: A fieldwork dilemma from Ghana. Anthropology Today, 19(1), 14-18.

Williams, J.M. (2010). Chieftaincy, the state and democracy: Political legitimacy in postapartheid South Africa. Bloomington and Indianapolis: Indiana University Press.

Wyllie, R. (1998). Not in our backyard: Opposition to tourism development in a Hawaiian community. Tourism Recreation Research, 23(1), 55-64. 
Yankah, K. (1995). Speaking for the chief: Okyeame and the politics of Akan royal oratory. Bloomington: Indiana University Press.

Yankholmes, A. \& McKercher, B. (2015) Understanding visitors to slavery heritage sites in Ghana. Tourism Management, 51, 22-32.

Yankholmes, A., Akyeampong, O.A., \& Dei, L.A. (2009) Residents' perceptions of Transatlantic Slave Trade attractions for tourism development in Danish-Osu, Ghana. Journal of Heritage Tourism, 4(4), 315-329. 


\section{Table 1: Description of study communities}

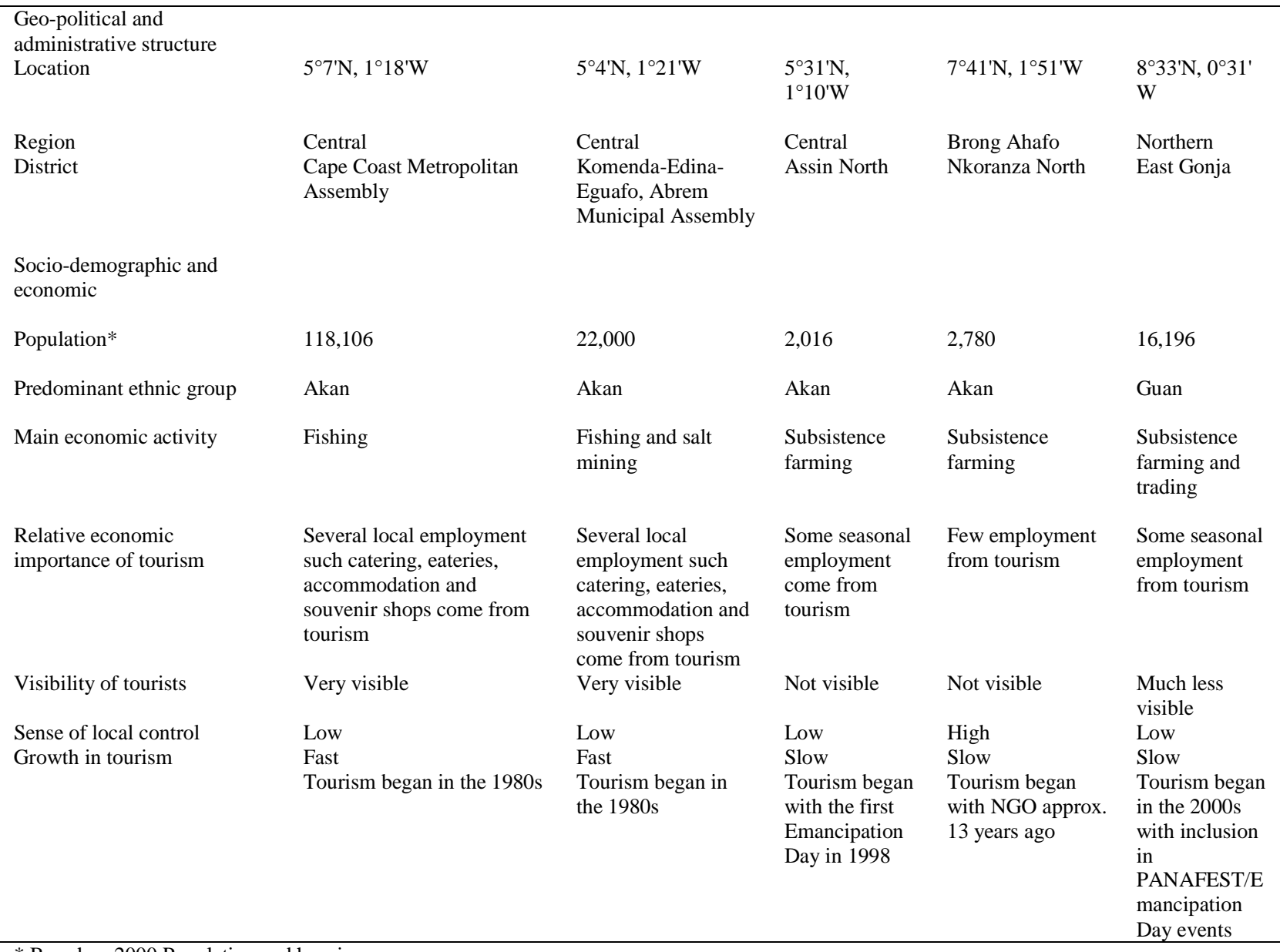

* Based on 2000 Population and housing census 
Table 2: List of participants

\begin{tabular}{|c|c|c|}
\hline Study site & Traditional area & Profile \\
\hline Cape Coast & Oguaa & $\begin{array}{l}\text { Osabarima Kwesi Atta II, late 60s; } \\
\text { installed } 1998\end{array}$ \\
\hline Elmina & Edina & $\begin{array}{l}\text { Nana Kwesi Amosi IV- Kyeidomehene; } \\
\text { Nana Takyi Akyei IV- Twafohene } e^{b} \text {; Mr. } \\
\text { Dadzie Mensah- Secretary to paramount } \\
\text { chief }\end{array}$ \\
\hline Assin Manso & Assin Apimanin & Barima Nkyi, late 60s; installed 1968 \\
\hline Bono Manso & Techiman Traditional area & Nana Menka Ameyaw; late 50s \\
\hline Salaga & Kpembe & $\begin{array}{l}\text { †Mobuwura Asumani Abubakar; late 50s; } \\
\text { installed } 1995\end{array}$ \\
\hline
\end{tabular}

† Chief of the autochthonous people of Kpembi

${ }^{\text {a }}$ Literally translates as rear commander (in the past, commanded the rear contingent in battle)

${ }^{\mathrm{b}}$ Chief Batman (commander of the king's guards) 


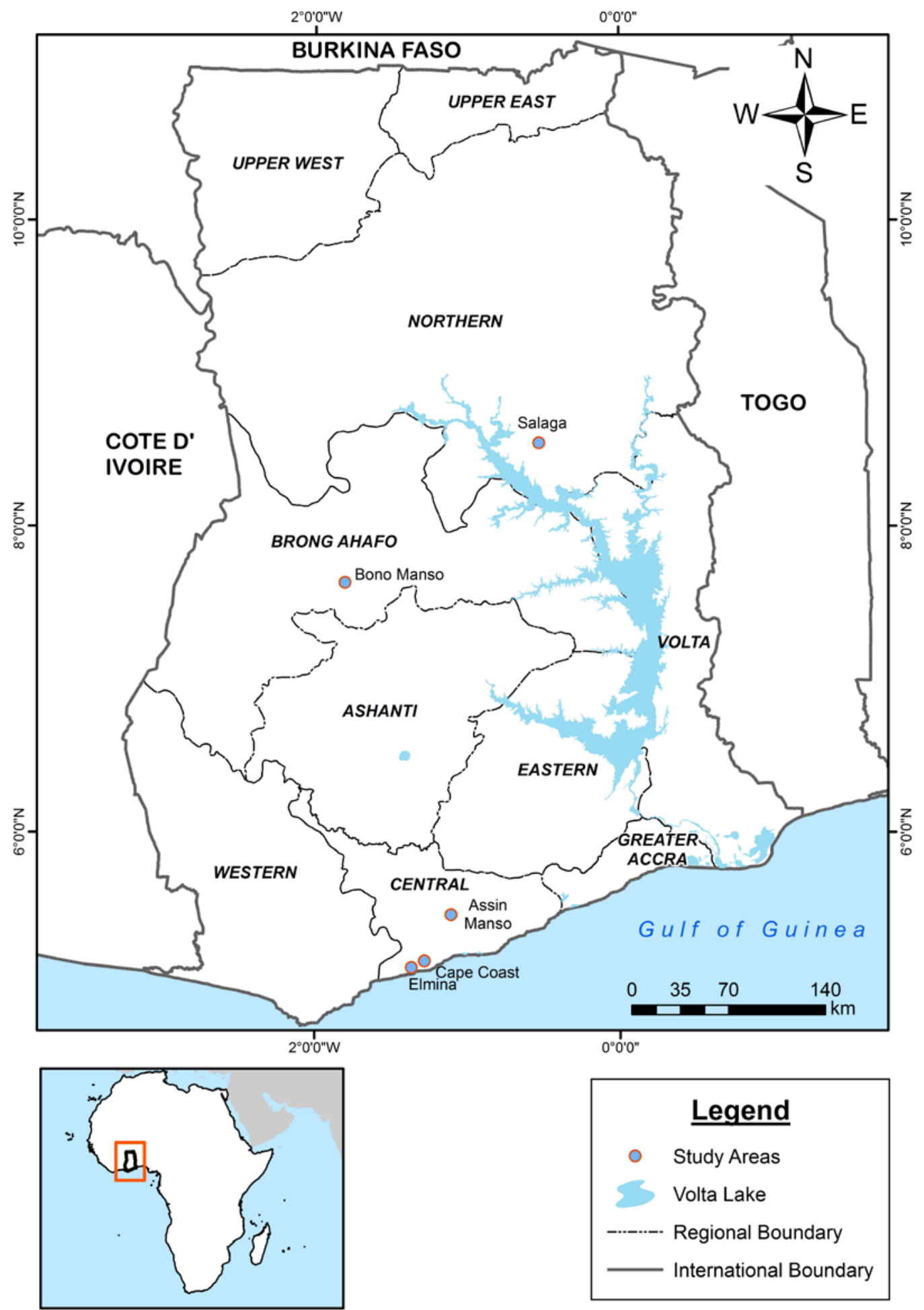

Figure 1 Map of Ghana showing study areas 


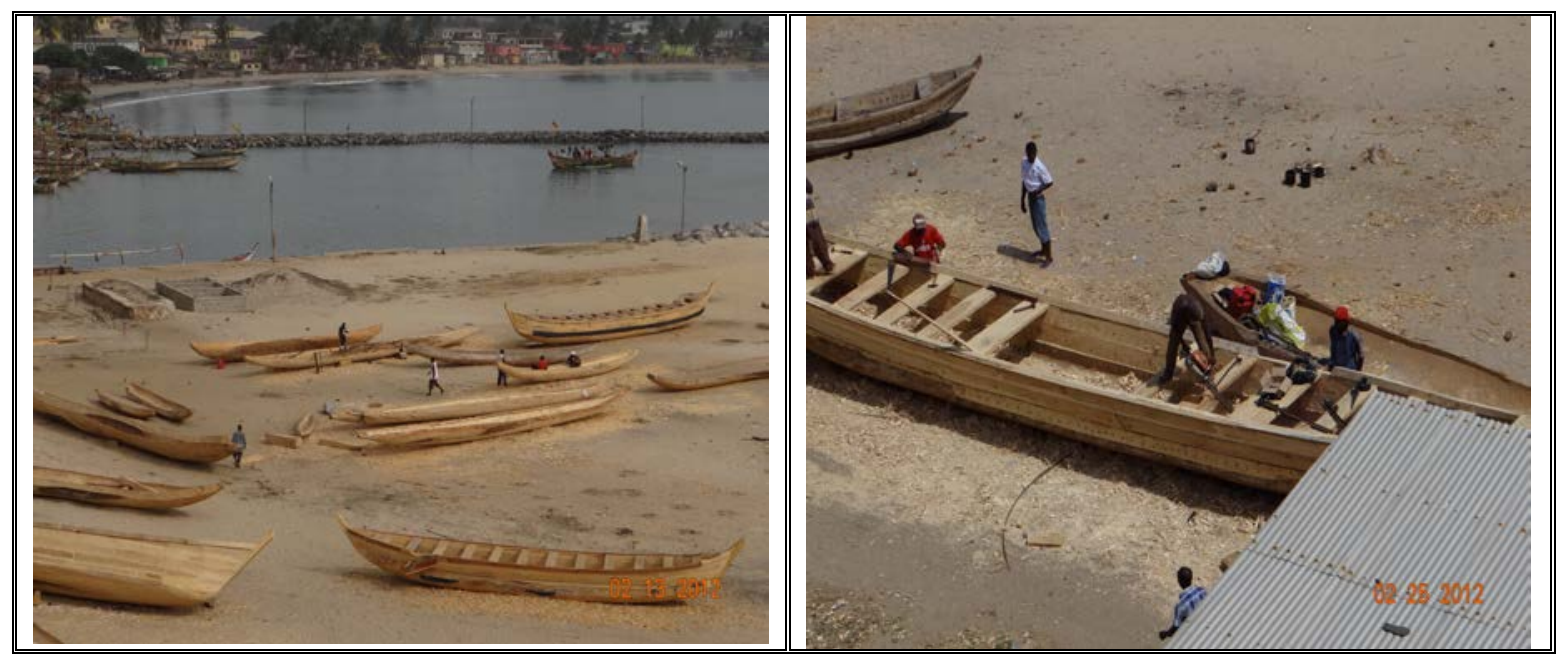

Figure 2 Boat builders ply their trade in the buffer zone of Elmina Castle 


\section{Higlights}

- Community characteristics are relevant to power structures and decision-making processes.

- Powerlessness was a common experience of traditional chiefs in this study.

- Descendants of 'slaves' were viewed as having less influence in tourism management decision making.

- Cooperative tourism planning and management is absent.

- Strong empirical support for Lukes’ three-dimensional view of power. 